Keywords: $M C U, A R P, I S D P$

Retention: Permanent

\title{
Sample Results from the Integrated Salt Disposition Program Macrobatch 5 Tank 21H Qualification Samples
}

T. B. Peters

S. D. Fink

March 2012

Savannah River National Laboratory Savannah River Nuclear Solutions Aiken, SC 29808

Prepared for the U.S. Department of Energy under

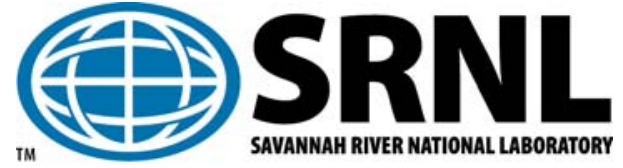
contract number DE-AC09-08SR22470. 
SRNL-STI-2012-00076

Revision 0

\section{DISCLAIMER}

This work was prepared under an agreement with and funded by the U.S. Government. Neither

the U.S. Government or its employees, nor any of its contractors, subcontractors or their employees, makes any express or implied:

1. warranty or assumes any legal liability for the accuracy, completeness, or for the use or results of such use of any information, product, or process disclosed; or

2. representation that such use or results of such use would not infringe privately owned rights; or

3. endorsement or recommendation of any specifically identified commercial product, process, or service.

Any views and opinions of authors expressed in this work do not necessarily state or reflect those of the United States Government, or its contractors, or subcontractors.

Printed in the United States of America

Prepared for

U.S. Department of Energy 


\section{REVIEWS AND APPROVALS}

AUTHORS:

T. B. Peters, Author, SRNL/SASP

Date

TECHNICAL REVIEW:

C. A. Nash, Technical Reviewer, SRNL/ACP

Date

APPROVAL:

S. D. Fink, SRNL/SSP, Manager

Date

S. L. Marra, SRNL/E\&CPT Research Programs, Manager

Date

M. T. Keefer, Engineering Technology Integration, Manager

Date

J. E. Occhipinti, Waste Solidification Engineering, Manager

Date 


\section{EXECUTIVE SUMMARY}

Savannah River National Laboratory (SRNL) analyzed samples from Tank 21H in support of qualification of Macrobatch (Salt Batch) 5 for the Integrated Salt Disposition Project (ISDP). This document reports partial results of the analyses of samples of Tank $21 \mathrm{H}$. No issues with the projected Salt Batch 5 strategy are identified.

A subsequent report will provide analyses related needed for the Performance Objectives Demonstration Document (PODD) as well as results from process demonstrations for the waste. 
AA - Atomic Absoption

AD - Analytical Development

AMP - ammonium molybdophosphate

ARP - Actinide Removal Project

CVHg - Cold Vapor Mercury

ESS - extraction, scrub, strip

IC - Ion Chromatography

ICPES - Inductively Coupled Plasma Emission Spectroscopy

ICPMS - Inductively Coupled Plasma Mass Spectroscopy

ISDP - Integrated Salt Disposition Program

MST - monosodium titanate

PODD - Performance Objectives Demonstration Document

PuTTa - plutonium thenoyl trifluoroacetone scintillation

RSD - relative standard deviation

SRNL - Savannah River National Laboratory

SRR - Savannah River Remediation

TIC-TOC - Total Inorganic Carbon-Total Organic Carbon

TTQAP - Task Technical and Quality Assurance Plan

TTR - Technical Task Request

WAC - Waste Acceptance Criteria

$\%$ RSD - percent relative standard deviation 


\subsection{Introduction}

This report covers the Tank $21 \mathrm{H}$ qualification sample results for Macrobatch (Salt Batch) 5 of the Integrated Salt Disposition Program (ISDP). A previous document covers initial characterization which includes results for a number of non-radiological analytes. ${ }^{1}$ This work was specified by Task Technical Request ${ }^{2}$ and by Task Technical and Quality Assurance Plan (TTQAP). ${ }^{3}$

Details for the work are contained in controlled laboratory notebooks. ${ }^{4}$

\subsection{Experimental Procedure}

Five Tank 21H samples (i.e., dip sample bottles HTF-21-11-114, HTF-21-11-115, HTF-21-11-116, HTF-21-11-117, and HTF-21-11-118) arrived at SRNL on October 13, 2011.

For this macrobatch, Tank $21 \mathrm{H}$ is used as the blend and preparation tank. This material will be transferred to Tank $49 \mathrm{H}$ where it will be combined with the heel from Macrobatch 4. In this qualification effort for Macrobatch 5, only samples from Tank $21 \mathrm{H}$ have been analyzed. In this campaign, the qualification and tank strategy ${ }^{5}$ indicates that analysis of Tank $49 \mathrm{H}$ is not needed as the material was qualified for Macrobatch 4. As long as the Tank $21 \mathrm{H}$ material is qualified, and the qualified Tank $49 \mathrm{H}$ material has not changed, then the blend of these two tanks will provide a usable composite.

All of the samples were optically clear, with no visible solids present. The researchers measured the density of the solution in each bottle to make sure that the samples pulled from each depth were relatively homogenous. Samples were well shaken before measuring. The density results were previously reported. ${ }^{1}$ Once the density was measured, the five samples were composited with customer concurrence.

\subsection{Results and Discussion}

In a previous document ${ }^{1}$, density, Inductively Coupled Plasma Emission Spectroscopy (ICPES), Ion Chromatography (IC) and ${ }^{137} \mathrm{Cs}$ results were reported for the Tank $21 \mathrm{H}$ composite. These results are also reported here for clarity (Table 1). Values in parentheses are the relative standard deviation (RSD). 
Table 1. Previous Results

\begin{tabular}{|c|c|c|c|}
\hline Analyte & Result (mg/L) & Analyte & Result (mg/L) \\
\hline Density & $1.301 \mathrm{~g} / \mathrm{mL}(0.75 \%)$ & $\mathrm{Sb}$ & $<10.7$ \\
\hline $\mathrm{Ag}$ & $<1.46$ & $\mathrm{Si}$ & $46.8(1.66 \%)$ \\
\hline $\mathrm{Al}$ & $7125(0.10 \%)$ & $\mathrm{Sn}$ & $<5.61$ \\
\hline $\mathrm{B}$ & $35.8(0.40 \%)$ & $\mathrm{Sr}$ & $<0.05$ \\
\hline $\mathrm{Ba}$ & $<0.52$ & $\mathrm{Th}$ & $<2.68$ \\
\hline $\mathrm{Be}$ & $<0.08$ & $\mathrm{Ti}$ & $<0.38$ \\
\hline $\mathrm{Ca}$ & $<0.56$ & $\mathrm{U}$ & $<32.7$ \\
\hline $\mathrm{Cd}$ & $0.850(1.66 \%)$ & $\mathrm{V}$ & $<0.47$ \\
\hline $\mathrm{Ce}$ & $<6.03$ & $\mathrm{Zn}$ & $4.40(0.64 \%)$ \\
\hline $\mathrm{Cr}$ & $41.0(0.34 \%)$ & $\mathrm{Zr}$ & $>0.25$ \\
\hline $\mathrm{Cu}$ & $1.29(23.7 \%)$ & $\mathrm{F}$ & $<10$ \\
\hline $\mathrm{Fe}$ & $5.54(0.64 \%)$ & $\mathrm{Cl}^{-}$ & $<500$ \\
\hline $\mathrm{Gd}$ & $<2.15$ & $\mathrm{Br}$ & $<500$ \\
\hline $\mathrm{K}$ & $324(2.40 \%)$ & Formate & $<10$ \\
\hline $\mathrm{La}$ & $<0.67$ & Nitrite & $25750(5.77 \%)$ \\
\hline $\mathrm{Li}$ & $10.4(0.68 \%)$ & Nitrate & $175000(5.27 \%)$ \\
\hline $\mathrm{Mg}$ & $<0.15$ & Phosphate & $485(13.7 \%)$ \\
\hline $\mathrm{Mn}$ & $<0.53$ & Sulfate & $7305(4.36 \%)$ \\
\hline $\mathrm{Mo}$ & $7.79(8.45 \%)$ & Oxalate & $242(20.5 \%)$ \\
\hline $\mathrm{Na}$ & $146000(0.49 \%)$ & TIC & $2860(2.97 \%)$ \\
\hline $\mathrm{Ni}$ & $<1.6$ & TOC & $220(5.14 \%)$ \\
\hline $\mathrm{P}$ & $168(0.84 \%)$ & Free Hydroxide & $2.08 \mathrm{M}(2.04 \%)$ \\
\hline $\mathrm{Pb}$ & $<7.16$ & $137 \mathrm{Cs}$ & $5.90 \mathrm{E}+07(0.00 \%)$ \\
\hline $\mathrm{S}$ & $2940(0.00 \%)$ & & \\
\hline & & & \\
\hline
\end{tabular}

The nickel (Ni) result converted into a concentration of $\mathrm{Ni}(\mathrm{OH})_{2}$ is $<2.53 \mathrm{mg} / \mathrm{L}$.

\subsection{Tank 21H Qualification Analyses}

The tank samples were analyzed by Analytical Development (AD) by the listed nonradiological methods (Table 2) and radiological (Table 3) methods. Analyses were performed in duplicate. Averages of the individual results, with the percent relative standard deviation (RSD) in parentheses, are reported in subsequent data tables. Shaded sample results indicate calculated values. 
Table 2. Non-Radiological Analyses

\begin{tabular}{|c|c|}
\hline Method & Analyte \\
\hline IC Cations & $\mathrm{NH}_{4}{ }^{+}$ \\
\hline TIC & total inorganic carbon \\
\hline TOC & total organic carbon \\
\hline AA-As & $\mathrm{As}$ \\
\hline AA-Se & $\mathrm{Se}$ \\
\hline CV-Hg & $\mathrm{Hg}$ \\
\hline HPLC & tetraphenylborate, phenol \\
\hline SVOA & tributylphosphate \\
\hline VOA & isopropanol, butanol, isobutanol \\
\hline
\end{tabular}

Table 3. Radiological Analyses

\begin{tabular}{|c|c|}
\hline Method & Analyte \\
\hline Tritium & ${ }^{3} \mathrm{H}$ \\
\hline${ }^{14} \mathrm{C}$ & ${ }^{14} \mathrm{C}$ \\
\hline gamma scan, Cs-removed & $\begin{array}{l}{ }^{60} \mathrm{Co},{ }^{94} \mathrm{Nb},{ }^{106} \mathrm{Ru},{ }^{125} \mathrm{Sb},{ }^{126} \mathrm{Sn}, \\
{ }^{144} \mathrm{Ce},{ }^{154} \mathrm{Eu},{ }^{155} \mathrm{Eu},{ }^{241} \mathrm{Am},{ }^{226} \mathrm{Ra},\end{array}$ \\
\hline${ }^{90} \mathrm{Sr}$ & ${ }^{90} \mathrm{Sr}$ \\
\hline${ }^{129} \mathrm{I}$ & ${ }^{129} \mathrm{I}$ \\
\hline gamma scan & ${ }^{134} \mathrm{Cs},{ }^{137} \mathrm{Cs}$ \\
\hline${ }^{232} \mathrm{U}$ & ${ }^{232} \mathrm{U}$ \\
\hline $\begin{array}{l}{ }^{238-241} \mathrm{Pu} \text { (filtered and unfiltered) (Plutonium } \\
\text { thenoyl trifluoroacetone scintillation) }\end{array}$ & ${ }^{238} \mathrm{Pu},{ }^{239 / 40} \mathrm{Pu},{ }^{241} \mathrm{Pu}$ \\
\hline $\mathrm{Am} / \mathrm{Cm}$ & ${ }^{241} \mathrm{Am},{ }^{243} \mathrm{Am},{ }^{244} \mathrm{Cm},{ }^{245} \mathrm{Cm}$ \\
\hline${ }^{59 / 63} \mathrm{Ni}$ & ${ }^{59 / 63} \mathrm{Ni}$ \\
\hline${ }^{99} \mathrm{Tc}$ & ${ }^{99} \mathrm{Tc}$ \\
\hline${ }^{147} \mathrm{Pr} /{ }^{151} \mathrm{Sm}$ & ${ }^{147} \mathrm{Pr} /{ }^{151} \mathrm{Sm}$ \\
\hline $\begin{array}{c}\text { Rad ICPMS (Inductively Coupled Plasma } \\
\text { Mass Spectroscopy) }\end{array}$ & $\begin{array}{l}\text { isotopes from mass number } 81 \text { to } \\
209 \text { and } 230 \text { to } 252 \text {, incl. }{ }^{233} \mathrm{U} \text { and } \\
\text { above, }{ }^{237} \mathrm{~Np},{ }^{230} \mathrm{Th},{ }^{232} \mathrm{Th}\end{array}$ \\
\hline Liquid Scintillation Counting & total alpha, total beta \\
\hline
\end{tabular}




\subsection{Tank 21H Qualification Results (non-radiological analytes)}

Free Hydroxide, IC Cations and Total Inorganic Carbon/Total organic Carbon (TIC/TOC) are listed in Table 4. The analytical uncertainty for each of these methods is $10 \%$.

Table 4. IC Cations, Free Hydroxide and TIC/TOC Results

\begin{tabular}{|c|c|}
\hline Analyte & Result (mg/L) \\
\hline $\mathrm{NH}_{4}{ }^{+}$ & $<50$ \\
\hline $\mathrm{TIC}$ & $2860(2.97 \%)$ \\
\hline TOC & $220(5.14 \%)$ \\
\hline carbonate & $\leq 0.238 \mathrm{M}$ \\
\hline Free Hydroxide & $2.08(2.04 \%) \mathrm{M}$ \\
\hline
\end{tabular}

The TIC and TOC results are in terms of $\mathrm{mg} / \mathrm{L}$ of carbon. If we assume that the entire TIC result is carbonate, this translates to a carbonate concentration of $0.238 \mathrm{M}$.

The results for the weight percent insoluble solids, phenol, tetraphenylborate, tributyl phosphate, isopropanol, methanol, isobutanol, butanol, arsenic, mercury, and selenium are listed in Table 5. The analytical uncertainty for all listed analyses is $20 \%$, except for the $\mathrm{wt} \%$ insoluble solids, which is $10 \%$.

Table 5. Miscellaneous Results (mg/L unless otherwise noted)

\begin{tabular}{|c|c|}
\hline Analyte & Result \\
\hline wt \% insoluble solids & $0.32 \mathrm{wt} \%(8.84 \%)$ \\
\hline phenol & $<10$ \\
\hline tetraphenylborate & $<10$ \\
\hline tributylphosphate & $<1$ \\
\hline isopropanol & $<0.25$ \\
\hline butanol & $<0.75$ \\
\hline isobutanol & $<0.75$ \\
\hline methanol & $\leq 190$ \\
\hline As & $0.322(11.2 \%)$ \\
\hline $\mathrm{Hg}$ & $88.2(10.6 \%)$ \\
\hline $\mathrm{Se}$ & $0.201(2.47 \%)$ \\
\hline
\end{tabular}


The TTR requested a TPB detection limit of $5 \mathrm{mg} / \mathrm{L}$ or less; however this resolution is not normally attainable. SRNL is in the process of trying to refine this method.

The oxalate concentration is $242 \mathrm{mg} / \mathrm{L}$, and the formate result is $317 \mathrm{mg} / \mathrm{L}$. The oxalate result is converted to the equivalent carbon result of $66 \mathrm{mg} / \mathrm{L}$. The formate result is converted to the equivalent carbon result of $82.7 \mathrm{mg} / \mathrm{L}$. Subtracting this result from the TOC result gives a remainder of $71.3 \mathrm{mg} / \mathrm{L}$ of carbon. If we assume all of this remainder carbon is in the form of methanol, this gives a calculated methanol result of $190 \mathrm{mg} / \mathrm{L}$. This methanol result should be considered an upper bound as no direct analytical method for methanol exists.

\subsection{Tank 21H Qualification Results (radiological analytes)}

The results of the radiological analysis are listed in Table 6 . The analytical uncertainty for RADICPMS samples are $20 \%$. Other analytical methods have varying uncertainties, typically $5-10 \%$ and are noted for single sample results.

Results given in italics indicate that one of the sample results was either below detection or quantification limits, in which case the value in the parentheses is the analytical uncertainty. Only quantifiable measured values are reported when available.

${ }^{90} \mathrm{Y}$ is calculated as equal to the ${ }^{90} \mathrm{Sr}$ result. ${ }^{106} \mathrm{Rh}$ is calculated as equal to the ${ }^{106} \mathrm{Ru}$ result. ${ }^{137 \mathrm{~m}} \mathrm{Ba}$ is calculated as $94.7 \%$ of the ${ }^{137} \mathrm{Cs}$ result (as seen in Table 1 ). ${ }^{6}$ The ${ }^{137} \mathrm{Cs}$ value was previously reported. ${ }^{1}{ }^{144} \mathrm{Pr}$ is calculated as equal to the ${ }^{144} \mathrm{Ce}$ result. The ${ }^{135} \mathrm{Cs}$ result assumes that all of mass 135 from the ICPMS result is ${ }^{135} \mathrm{Cs}$. The ${ }^{232} \mathrm{Th}$ result assumes that all of mass 232 from the ICPMS result is ${ }^{232} \mathrm{Th}$. The Total Alpha value is calculated by adding all the alpha results together and treating the less-than results as real values. Thus, this value is biased high. Total gamma is calculated as the sum of the ${ }^{137} \mathrm{Cs},{ }^{134} \mathrm{Cs}$, ${ }^{135} \mathrm{Cs},{ }^{60} \mathrm{Co},{ }^{94} \mathrm{Nb},{ }^{106} \mathrm{Ru},{ }^{125} \mathrm{Sb},{ }^{126} \mathrm{Sn},{ }^{144} \mathrm{Ce},{ }^{144} \mathrm{Pr},{ }^{154} \mathrm{Eu},{ }^{155} \mathrm{Eu}$, and ${ }^{226} \mathrm{Ra}$. The ${ }^{238} \mathrm{Pu}$ (soluble or total), ${ }^{239 / 40} \mathrm{Pu}$, and ${ }^{241} \mathrm{Pu}$ results are from radiocounting, while the other $\mathrm{Pu}$ results are from ICPMS.

The Total Soluble Plutonium value is calculated by adding all the plutonium results together and treating the measurements less-than the method detection limits as equal to the method detection limit. Thus, this value is conservative. The Total Soluble Uranium value is calculated by adding all the uranium results together and treating the values reported as less-than the method detection limits as equal to the method detection limit. Thus, this value is conservative.

The high RSD in the ${ }^{90} \mathrm{Sr}$ result is due to the two disparate results $(1.28 \mathrm{E}+05$ and $2.58 \mathrm{E}+05 \mathrm{pCi} / \mathrm{mL})$. This method requires an isotopic extraction and decay and can occasionally give duplicate results with high RSD. The high RSD in the ${ }^{232} \mathrm{U}$ result is again due to two disparate results $(7.25$ and $1.42 \mathrm{pCi} / \mathrm{mL})$ which is due to being very close to the method detection limit. 


\section{Table 6. Radiological Results of Tank 21H Analyses for Macrobatch 5} (pCi/mL unless otherwise noted)

\begin{tabular}{|c|c|c|c|}
\hline Analyte & Average Result & Analyte & Average Result \\
\hline${ }^{3} \mathrm{H}$ & $9.46 \mathrm{E}+02(12.3 \%)$ & ${ }^{232} \mathrm{Th}$ & $<1.10 \mathrm{E}-03$ \\
\hline${ }^{14} \mathrm{C}$ & $7.20 \mathrm{E}+02(10 \%)$ & ${ }^{232} \mathrm{U}$ & $4.33 \mathrm{E}+00(95.0 \%)$ \\
\hline${ }^{59} \mathrm{Ni}$ & $<2.00 \mathrm{E}+01$ & ${ }^{233} \mathrm{U}$ & $<9.68 \mathrm{E}+01$ \\
\hline${ }^{63} \mathrm{Ni}$ & $<4.06 \mathrm{E}+02$ & ${ }^{234} \mathrm{U}$ & $9.00 \mathrm{E}+01(28.5 \%)$ \\
\hline${ }^{60} \mathrm{Co}$ & $<5.63 \mathrm{E}+00$ & ${ }^{235} \mathrm{U}$ & $1.94 \mathrm{E}-01(3.46 \%)$ \\
\hline${ }^{90} \mathrm{Sr}$ & $1.93 \mathrm{E}+05(47.8 \%)$ & ${ }^{236} \mathrm{U}$ & $1.08 \mathrm{E}+00(6.77 \%)$ \\
\hline${ }^{90} \mathrm{Y}$ & $1.93 \mathrm{E}+05(47.8 \%)$ & ${ }^{238} \mathrm{U}$ & $3.70 \mathrm{E}+00(3.86 \%)$ \\
\hline${ }^{94} \mathrm{Nb}$ & $<6.08 \mathrm{E}+00$ & ${ }^{237} \mathrm{~Np}$ & $3.39 \mathrm{E}+00(7.93 \%)$ \\
\hline${ }^{99} \mathrm{Tc}$ & $2.28 \mathrm{E}+04(5.87 \%)$ & ${ }^{238} \mathrm{Pu}(\mathrm{soluble})$ & $1.49 \mathrm{E}+04(5.57 \%)$ \\
\hline${ }^{106} \mathrm{Ru}$ & $<8.19 \mathrm{E}+01$ & ${ }^{238} \mathrm{Pu}($ total $)$ & $1.46 \mathrm{E}+04(4.56 \%)$ \\
\hline${ }^{106} \mathrm{Rh}$ & $<8.19 \mathrm{E}+01$ & ${ }^{239} / 40 \mathrm{Pu}$ & $1.49 \mathrm{E}+03(6.00 \%)$ \\
\hline${ }^{125} \mathrm{Sb}$ & $<5.99 \mathrm{E}+01$ & ${ }^{242} \mathrm{Pu}$ & $<5.22 \mathrm{E}+03$ \\
\hline${ }^{126} \mathrm{Sn}$ & $1.93 \mathrm{E}+02(3.46 \%)$ & ${ }^{244} \mathrm{Pu}$ & $<3.82 \mathrm{E}+01$ \\
\hline${ }^{129} \mathrm{I}$ & $1.30 \mathrm{E}+01(6.38 \%)$ & ${ }^{241} \mathrm{Am}$ & $<1.77 \mathrm{E}-01$ \\
\hline${ }^{134} \mathrm{Cs}$ & $<5.54 \mathrm{E}+03$ & ${ }^{243} \mathrm{Am}$ & $<7.6 \mathrm{E}+00$ \\
\hline${ }^{135} \mathrm{Cs}$ & $2.81 \mathrm{E}+02(2.90 \%)$ & ${ }^{244} \mathrm{Cm}$ & $<3.98 \mathrm{E}+00$ \\
\hline${ }^{137 m} \mathrm{Ba}$ & $5.59 \mathrm{E}+07(0.00 \%)$ & ${ }^{245} \mathrm{Cm}$ & $<1.13 \mathrm{E}+01$ \\
\hline${ }^{144} \mathrm{Ce}$ & $<7.70 \mathrm{E}+01$ & Total Alpha & $<7.47 \mathrm{E}+03$ \\
\hline${ }^{144} \mathrm{Pr}$ & $<7.70 \mathrm{E}+01$ & Total Beta & $6.55 \mathrm{E}+07(6.32 \%)$ \\
\hline${ }^{147} \mathrm{Pm}$ & $<1.80 \mathrm{E}+02$ & Total Gamma & $5.90 \mathrm{E}+07$ \\
\hline${ }^{151} \mathrm{Sm}$ & $<1.53 \mathrm{E}+02$ & Total Sol. Pu (mg/L) & $4.18 \mathrm{E}-02$ \\
\hline${ }^{154} \mathrm{Eu}$ & $<1.53 \mathrm{E}+01$ & Total Sol. U $(\mathrm{mg} / \mathrm{L})$ & $1.12 \mathrm{E}+01$ \\
\hline${ }^{155} \mathrm{Eu}$ & $<3.62 \mathrm{E}+01$ & & \\
\hline 226 & $<3.12 \mathrm{E}+02$ & & \\
\hline & & & \\
\hline
\end{tabular}

\subsection{Conclusions}

Results of the analyses of the Tank $21 \mathrm{H}$ samples from this report in conjunction with the findings of the previous report, ${ }^{1}$ indicates that the material does not display any unusual characteristics.

\footnotetext{
${ }^{\Upsilon}$ The Waste Acceptance Criteria (Tank 50 WAC) limit is for total ${ }^{238} \mathrm{Pu}$. There is an Actinide Removal Process (ARP) limit of $7.93 \mathrm{E}+05 \mathrm{pCi} / \mathrm{mL}$ for soluble ${ }^{238} \mathrm{Pu}$. Unlike most samples, this one was deliberately not filtered before analysis.
} 


\subsection{References}

${ }^{1}$ T. B. Peters, S. D. Fink, "Results of Initial Analyses of the Macrobatch 5 Tank $21 \mathrm{H}$ Qualification Samples", SRNL-STI-2012-00025, January 2012.

${ }^{2}$ A. R. Shafer, “Qualification of ISDP Salt Batch 5”, HLW-DWPF-TTR-2012-0001, October 17, 2011.

${ }^{3}$ T. B. Peters and S. D. Fink, "Task Technical and Quality Assurance Plan for ISDP Salt Batch 5 Sample Qualification", SRNL-RP-2011-01629, Rev.0, November 16, 2011.

${ }^{4}$ T. B. Peters, "ISDP5", SRNL-NB-2012-00017, January 30, 2012.

${ }^{5}$ S. E. Campbell, "Qualification and Sampling Strategy for ISDP Batch 5 to Obtain Compliance to 512-S, DWPF, Tank Farm, and Saltstone Waste Acceptance Criteria”, X-ESR-H-00347, November 17, 2011.

${ }^{6}$ http://www.nndc.bnl.gov, E. Browne, J. K. Tuli Citation: Nuclear Data Sheets 108, 2173 (2007) 


\section{Distribution:}
A. B. Barnes, 999-W
S. D. Fink, 773-A
B. J. Giddings, 786-5A
C. C. Herman, 999-W
S. L. Marra, 773-A
F. M. Pennebaker, 773-42A

M. T. Keefer, 241-156H

R. E. Edwards, Jr., 704-56H

E. J. Freed, $766 \mathrm{H}$

D. J. Martin, 241-152H

M. W. Geeting, 241-152H

S. P. McLeskey, 704-27S

B. A. Gifford, 704-56H

S. E. Campbell, 241-197H

E. W. Harrison, 704-60H

C. E. Duffey, 241-152H

T. T. Le, 241-197H

J. E. Occhipinti, 704-S

D. C. Sherburne, 704-S

J. W. Ray, 704-S

A. R. Shafer, 241-197H

C. K. Chiu, 704-27S

H. H. Elder, 704-24S

P. R. Jackson, 703-46A

T. B. Peters, 773-42A

C. A. Nash, 773-42A

M. R. Poirier, 773-42A

F. F. Fondeur, 773-A 